\title{
Barriers to Diversity and Academic Promotion in Dermatology: Recommendations Moving Forward
}

\author{
Justin D. Lu ${ }^{a} \quad$ Irina Sverdlichenko ${ }^{b}$ Javed Siddiqi ${ }^{c}$ Faisal Khosa ${ }^{d}$ \\ ${ }^{a}$ Michael G. DeGroote School of Medicine, McMaster University, Hamilton, ON, Canada; ${ }^{b}$ Faculty of Medicine, \\ University of Toronto, Toronto, ON, Canada; ' Arrowhead Neurosurgical Medical Group, Colton, CA, USA; \\ ${ }^{\mathrm{d}}$ Department of Radiology, Vancouver General Hospital, Vancouver, BC, Canada
}

Dermatology continues to be one of the least diverse medical specialties in North America. Only 3\% of dermatologists are Black, even though $12.8 \%$ of Americans are Black [1]. In addition, only $4.2 \%$ of dermatologists are Hispanic compared to $16.3 \%$ of the general population being Hispanic [1]. Based on the US Census, it has been projected that by the year 2044 more than half of the US population will belong to minorities [2]. Ethnic diversity issues have also been noted in other areas of the world. Ethnic minority graduates of UK medical schools have worse outcomes during recruitment for foundation, specialty training, and consultant posts [3]. Furthermore, in Israel, a small qualitative review identified issues of discrimination against Arab candidates applying for hospital positions [4]. With the increasing representation of minorities, diversification of the healthcare workforce is crucial for providing high-quality patient care. The Association of American Medical Colleges (AAMC) used the term "underrepresented minority" (URM) to describe racial and ethnic populations that are underrepresented in the medical profession relative to their numbers in the general population [1].

Assessing patient outcomes, quality of healthcare services, and patient satisfaction is highly complex and mul- tifaceted; however, minority patients are more likely to choose a URM physician and are more satisfied and engaged with their care when it is provided by a URM physician [1]. Minority patients are also more likely to rate race-concordant physicians as more participatory in their care than race-discordant physicians [1]. A recent survey of 92 patients found that $44 \%$ of Hispanic and $42 \%$ of Black patients reported "some level of importance" to receiving care from a race-concordant dermatologist, while 98\% of White patients reported that it was not important at all $(p<0.001)$ [5]. Race-concordant physicians may also be better able to relate to their patients because of similar life experiences and culture, according to the reports of Black patients receiving care by race-concordant dermatologists [6]. URM physicians are also more likely to serve their communities, which may include minorities and patients with limited access to healthcare and a poor health status [1]. In addition, increased diversity in the learning environment may prepare trainees to serve diverse populations.

This is very significant in dermatology, as skin cancer mortality is disproportionately higher in Blacks and Hispanics. Although the incidence of skin cancer is lower in racial and ethnic groups, Black and Hispanic karger@karger.com

www.karger.com/drm

Karger'
(C) 2021 S. Karger AG, Basel

(1)
Correspondence to:

Faisal Khosa, fkhosa@ hotmail.com 
Table 1. Barriers to academic promotion, their significance, and potential actions and solutions in dermatology

\begin{tabular}{|c|c|c|}
\hline Barriers to diversity & Significance & Potential actions and solutions \\
\hline $\begin{array}{l}\text { Competitive } \\
\text { requirements for } \\
\text { dermatology residency }\end{array}$ & $\begin{array}{l}\text { - } 82 \% \text { of dermatology programs require a very competitive Step } 1 \text { score [18] } \\
\text { - Demographic differences in Step } 1 \text { scores, with White and Asian medical } \\
\text { students outperforming Black and Hispanic medical students [20] }\end{array}$ & $\begin{array}{l}\text { - Utilizing a holistic review process, with less emphasis on Step } 1 \text { scores, } \\
\text { research, and publications } \\
\text { - More consideration for EDI (equity, diversity, inclusion) work and } \\
\text { on-site elective performance }\end{array}$ \\
\hline The lack of role models & $\begin{array}{l}\text { - Lack of women and minorities in senior roles in dermatology [2] } \\
\text { - Women in lower ranks are empowered by perceiving senior female faculty } \\
\text { members as their role models [16] } \\
\text { - Having a woman dermatologist as a leader positively correlates with } \\
\text { women in the faculty [21] }\end{array}$ & $\begin{array}{l}\text { - Making diversity an explicit goal in the dermatology faculty } \\
\text { - Creating a diversity taskforce and recruiting those with EDI experience } \\
\text { - Promotion and support for women and minorities in senior roles by } \\
\text { faculty and staff } \\
\text { - Support faculties already involved in diversity and mentorship } \\
\text { - Establish networks for women to look beyond their institutions for role } \\
\text { models }\end{array}$ \\
\hline $\begin{array}{l}\text { A lack of formal } \\
\text { mentoring }\end{array}$ & $\begin{array}{l}\text { - Having a mentor is associated with overall satisfaction, research } \\
\text { productivity, and stress reduction }[22] \\
\text { - Mentorship increased retention of URMs (underrepresented minorities) } \\
\text { and women in junior faculties }[17,23]\end{array}$ & $\begin{array}{l}\text { - Recruit more academic minorities and women to serve as mentors } \\
\text { - Increase URM representation in residency training programs } \\
\text { - Sponsorship and support by dermatology leaders }\end{array}$ \\
\hline $\begin{array}{l}\text { Implicit, explicit, } \\
\text { and cultural biases }\end{array}$ & $\begin{array}{l}\text { - URMs report microaggressions and implicit, explicit, and cultural bias [24] } \\
\text { - URMs report minority tax [25] } \\
\text { - Chairs acknowledge gender bias played a significant role in advancement } \\
\text { decisions [14] } \\
\text { - Leaders are more likely to select people like themselves, which tend to be } \\
\text { men [26] }\end{array}$ & $\begin{array}{l}\text { - Improve the understanding of health disparities especially for people of } \\
\text { color } \\
\text { - Workshops and training to address biases } \\
\text { - Join ongoing diversity efforts } \\
\text { - Increase the number of minority faculties } \\
\text { - Create an open forum for minorities and women to discuss issues as a } \\
\text { way of processing experiences of bias }\end{array}$ \\
\hline $\begin{array}{l}\text { A lack of institutional } \\
\text { support }\end{array}$ & $\begin{array}{l}\text { - Lack of support and collegial institutional environment for female } \\
\text { dermatologists [12] } \\
\text { - Lack of career development programs for women [12] } \\
\text { - Underrepresentation of named lectureships and awards for female } \\
\text { dermatologists [27] }\end{array}$ & $\begin{array}{l}\text { - Review faculty criteria to ensure that they are objective and equitable } \\
\text { - Create a departmental diversity task force } \\
\text { - Engage in more demographic and social studies on current medical } \\
\text { students, residents, physicians, and faculties in dermatology to influence } \\
\text { change } \\
\text { - Increase support and sponsorship for career development such as } \\
\text { awards and lectureships }\end{array}$ \\
\hline $\begin{array}{l}\text { Rigid promotional } \\
\text { systems and overreliance } \\
\text { on research productivity }\end{array}$ & $\begin{array}{l}\text { - Promotional systems value full-time commitments [14] } \\
\text { - Promotional systems favor research productivity over clinical educators } \\
\text { [15] } \\
\text { - More male dermatologists occupy investigative career tracks, while females } \\
\text { predominantly occupy clinical educator tracks [12] }\end{array}$ & $\begin{array}{l}\text { - Give equivalence to clinical work and teaching compared to research } \\
\text { productivity in the promotional process and selection } \\
\text { - Create more family-friendly career tracks such as flexible or part-time } \\
\text { commitments, especially in early investigative career tracks and tenure } \\
\text { tracks }\end{array}$ \\
\hline
\end{tabular}

EDI, equity, diversity and inclusion; URM, underrepresented minority.

patients present with more advanced melanomas, resulting in worse prognosis and higher mortality [7]. In a review by the California Cancer Registry, even after adjustments for age, sex, histology, lesion site, treatment, and socioeconomic status, an increased risk of death was observed for Blacks compared to non-Hispanic Whites [7]. In a study on Black patients' assessment of their care in a Skin of Color Clinic, patients reported feeling that Black dermatologists had better knowledge of black skin disorders than their non-Black counterparts [6]. Thus, having a diverse physician faculty and workforce may improve access to care in minority and vulnerable populations and potentially lead to better health outcomes.

Combined with recent evidence that female dermatologists are underrepresented in senior academic positions [2], we discussed the barriers to diversity in dermatology and the potential solutions to ensure equity, diversity, and inclusion (EDI) in academic dermatology across the USA (Table 1). According to the AAMC faculty data, women represented approximately $10 \%$ of full professors from 1990 to 2006, which has since increased to $28.9 \%$ in 2007-2018 [2, 8]. However, this small increase over the past 3 decades suggests that barriers to academic promotion persist for women. In other parts of the world, women also face challenges achieving leadership positions. For instance, in Germany, while $60 \%$ of medical-school graduates are female, only $10 \%$ of the leading positions at university hospitals are held by women [9]. Japan still experiences gender disparity across leadership positions in disciplines such as endocrinology [10]. A transcontinental thematic analysis found that males comprised the majority in leadership positions across the top 100 medical schools in the world [11].

In the USA, female dermatologists are less likely than men to be promoted despite equivalent work hours, publi- 
cations, and adjustment for age [12]. Several barriers hinder women from pursuing academia. Historically, institutions value research productivity, inherently biasing against the clinical and teaching faculties, which are predominantly female ( $81.5 \%$ females vs. $50 \%$ males in a national survey) [12]. Women report more family and childcare responsibilities than their male counterparts, which hinders the pursuit of academic endeavors and contributes to burnout [13]. Rigid promotional systems favor a traditional uninterrupted work model over a fixed time period that often fails to accommodate flexible work hours, something needed during child-bearing and child-rearing years [14, 15]. A lack of mentorship and role models has been reported by female dermatologists [12]. Mentorship increases retention of minority physicians in junior faculties [16]. Furthermore, having a female dermatologist as a leader positively correlates with more females working on their teams [17]. These barriers may contribute towards choosing a clinical career and/ or dedicating less time to scholarly activities, leading to slower promotion in academia.

Only $2.7 \%$ of US dermatologists are Black or Hispanic, suggesting minorities are not pursuing or matching into dermatology [2]. Dermatology is one of the most competitive specialties, with $82 \%$ of programs requiring a very competitive US Medical Licensing Examination (USMLE) Step 1 score [18]. However, the recent change to pass/fail for 2022 is a unique opportunity to promote a more holistic review process of applicants and advance diversity in dermatology [19].

Moving forward, we propose recommendations for improving diversity in dermatology (Table 1). Diversity should be made an explicit goal within the faculty. For example, by creating a departmental diversity task force where diversity is pursued in the appointment and selection committees. This may include consideration of working on EDI when selecting for departmental and university leadership. To encourage mentorship, academic women and minorities should be provided with incentives and compensation for their activities. Networks should be established to encourage members to find mentors beyond their institution. Creating familyfriendly career tracks through flexible or part-time opportunities would support the careers of women, especially in early investigative career tracks and tenure tracks. Utilizing a more holistic review, with less emphasis on grades and publications, as well as early mentorship could reduce the current bottleneck for diversity within dermatology residents (Table 1).

Further research is required to investigate and mitigate the factors associated with gender and minority differences in dermatology. Efforts at all levels are needed to foster the careers of female and minority faculty to ensure their equitable representation at all levels in academic dermatology.

\section{Key Message}

Barriers to gender and racial diversity persist in academic dermatology.

\section{Conflict of Interest Statement}

Dr. Khosa is the recipient of the AFMC-May Cohen Equity, Diversity and Gender Award (2020); Canadian Association of Radiologists - Young Investigator Award (2019); Rising Star Exchange Scholarship Program of French Society of Radiology (2019); and Humanitarian Award of the Association of Physicians of Pakistani Descent of North America (2019). The other authors have no conflicts of interest to declare.

\section{Funding Sources}

There are no funding sources to declare.

\section{Author Contributions}

J.D.L. conducted the literature review and wrote the manuscript. I.S. assisted with the literature review. J.S. and F.K. conceptualized the project and reviewed the manuscript.

\section{References}

Barriers to Diversity and Academic

Promotion in Dermatology
1 Pandya AG, Alexis AF, Berger TG, Wintroub $B U$. Increasing racial and ethnic diversity in dermatology: A call to action. J Am Acad Dermatol. 2016 Mar;74(3):584-7.

2 Lu JD, Tiwana S, Das P, Siddiqi J, Khosa F. Gender and racial underrepresentation in academic dermatology positions in the United States: a retrospective, cross-sectional study from 2007 to 2018. J Am Acad Dermatol. 2020 Nov;83(5):1513-6.
3 Woolf K. Differential attainment in medical education and training. BMJ. 2020 Feb; 368:m339.

4 Keshet Y, Popper-Giveon A. Race-based experiences of ethnic minority health professionals: Arab physicians and nurses in Israeli public healthcare organizations. Ethn Health. 2018 May;23(4):442-59. 
5 Venkatesh KP, Nelson K, Friedman A. Sociocultural attitudes and perceptions of potential barriers to care for dermatology patients. J Am Acad Dermatol. 2020, Online ahead of print.

6 Gorbatenko-Roth K, Prose N, Kundu RV, Patterson S. Assessment of Black Patients' Perception of Their Dermatology Care. JAMA Dermatol. 2019 Aug;155(10):1129-34.

7 Cress RD, Holly EA. Incidence of cutaneous melanoma among non-Hispanic whites, Hispanics, Asians, and Blacks: an analysis of California Cancer Registry data, 1988-93. Cancer Causes Control. 1997 Mar;8(2):246-52.

8 Feramisco JD, Leitenberger JJ, Redfern SI, Bian A, Xie XJ, Resneck JS Jr. A gender gap in the dermatology literature? Cross-sectional analysis of manuscript authorship trends in dermatology journals during 3 decades. J Am Acad Dermatol. 2009 Jan;60(1):63-9.

9 Lawson McLean A. Women in German Neurosurgery: Status and Representation at Annual National Meetings. Acta Neurochir (Wien). $2020 \mathrm{Feb} ; 162(2): 231-6$.

10 Katai M, Sakurai K, Fujita M, Yamamoto M, Hotta Suzuki M; Japan Endocrine Society Women Endocrinologists Association (JESWe-Can). Reducing the gender gap in academic activities: a 10-year progress report by the Japan Endocrine Society Women Endocrinologists Association (JES-We-Can). Endocr J. 2019 Apr;66(4):359-68.

11 Abdellatif W, Ding J, Jalal S, Chopra S, Butler J, Ali IT, et al. Leadership Gender Disparity Within Research-Intensive Medical Schools: A Transcontinental Thematic Analysis. J Contin Educ Health Prof. 2019;39(4):243-50.
12 Sadeghpour M, Bernstein I, Ko C, Jacobe H. Role of sex in academic dermatology: results from a national survey. Arch Dermatol. 2012 Jul;148(7):809-14.

13 Cassidy-Vu L, Beck K, Moore JB. Burnout in Female Faculty Members. J Prim Care Community Health. 2017 Apr;8(2):97-9.

14 Yedidia MJ, Bickel J. Why aren't there more women leaders in academic medicine? the views of clinical department chairs. Acad Med. 2001 May;76(5):453-65.

15 Beasley BW, Simon SD, Wright SM; The Prospective Study of Promotion in Academia (Prospective Study of Promotion in Academia). A time to be promoted. J Gen Intern Med. 2006 Feb;21(2):123-9.

16 Steele MM, Fisman S, Davidson B. Mentoring and role models in recruitment and retention: a study of junior medical faculty perceptions. Med Teach. 2013 May;35(5):e1130-8.

17 Kosoko-Lasaki O, Sonnino RE, Voytko ML. Mentoring for women and underrepresented minority faculty and students: experience at two institutions of higher education. J Natl Med Assoc. 2006 Sep;98(9):1449-59.

18 Chen A, Shinkai K. Rethinking How We Select Dermatology Applicants-Turning the Tide. JAMA Dermatol. 2017 Mar;153(3):25960.

19 Chaudhry HJ, Katsufrakis PJ, Tallia AF. The USMLE Step 1 Decision: An Opportunity for Medical Education and Training. JAMA. 2020 May;323(20):2017-8.
20 Rubright JD, Jodoin M, Barone MA. Examining Demographics, Prior Academic Performance, and United States Medical Licensing Examination Scores. Acad Med. 2019 Mar; 94(3):364-70.

21 Shah A, Jalal S, Khosa F. Influences for gender disparity in dermatology in North America. Int J Dermatol. 2018 Feb;57(2):171-6.

22 Eby LT, Allen TD, Evans SC, Ng T, Dubois D. Does Mentoring Matter? A Multidisciplinary Meta-Analysis Comparing Mentored and Non-Mentored Individuals. J Vocat Behav. 2008 Apr;72(2):254-67.

23 Daley S, Wingard DL, Reznik V. Improving the retention of underrepresented minority faculty in academic medicine. J Natl Med Assoc. 2006 Sep;98(9):1435-40.

24 Osseo-Asare A, Balasuriya L, Huot SJ, Keene D, Berg D, Nunez-Smith M, et al. Minority Resident Physicians' Views on the Role of Race/Ethnicity in Their Training Experiences in the Workplace. JAMA Netw Open. 2018 Sep;1(5):e182723.

25 Campbell KM, Rodríguez JE. Addressing the Minority Tax: Perspectives from Two Diversity Leaders on Building Minority Faculty Success in Academic Medicine. Acad Med. 2019 Dec;94(12):1854-7.

26 Villanueva AM, Kaye D, Abdelhak SS, Morahan PS. Comparing selection criteria of residency directors and physicians' employers. Acad Med. 1995 Apr;70(4):261-71.

27 Silver JK, Slocum CS, Bank AM, Bhatnagar S, Blauwet CA, Poorman JA, et al. Where Are the Women? The Underrepresentation of Women Physicians among Recognition Award Recipients from Medical Specialty Societies. PM R. 2017 Aug;9(8):804-15. 